\title{
Science Concepts According to Syed Hussein Nasr
}

\author{
Hasan Bakti Nasution ${ }^{1}$, Katimin' ${ }^{2}$, Salahuddin Harahap ${ }^{3}$ \\ ${ }^{1,2,3}$ Universitas Islam Negeri Sumatera Utara, Medan, Indonesia \\ purjaazhar@gmail.com,solhar08@gmail.com
}

\begin{abstract}
This Study aims to find out science concepts according Syed Hussein Nasr. The methodology of science in Islam is based on an epistemology that is fundamentally different from the epistemology that is dominant in modern Western science. For him, faith in the revelation of the Qur'an will reveal all the possibilities that exist in human reason. Submission to revelation, at every level makes sense capable of actualizing these possibilities. The development of Muslim reason is based on a complete awareness of this principle. In this perspective, in solving philosophical and scientific problems. Hence, it is understandable why purification of the soul is seen as an integral part of the methodology of knowledge. The purification of the soul is the main concern, for the protection and proper use of human reason. The religious and spiritual atmosphere created from the Koran at the same time removes obstacles to the development of a normal and optimal mind in the right way. Intellect here, is used in the sense of origin, intellectus (Latin) or nous (Greek).
\end{abstract}

Keywords science, concepts, Syed Hussein Nasr

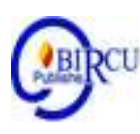

\section{Introduction}

Modern civilization has shown very fundamental changes in human life in almost all aspects, including aspects of science. Since the time of Rene Descartes (d.1650 AD), the wave of modernization, especially in the field of physics, has led to major revolutions in the scientific tradition which have triggered a shift in the human perspective on science. The post-modernization paradigm shift in science is marked by two of its most fundamental characteristics, namely the strengthening of rationality and materiality that have shaped the mindset and mentalities of humans, including scientists, to become very rational and materialistic.

The revolutions in the field of science have also shown that the development of science that has occurred to date is increasingly far from ethical, aesthetic and spiritual values. In other words, science slowly begins to break away from the values of religiosity, sanctity, closeness, and spirituality. This is due to the strong influence of Cartesian-Newtonian logic, positivism and Post-Modernism on changes in the mindset of modern scientists, especially for those who are immersed in the grip of materialism, mechanism, and bound by modern logic (positivistic, atomistic). The Western philosophy of rationalism initiated by Rene Descartes has shaped the mindset and belief of scientists who are so great in rationality and reason and show their strong rejection of the things that are irrational and spiritual in science. Even though without realizing it, the presence of this mindset has slowly caused them to be trapped in a rigid circle of materialism and deterministic mechanisms.

The recent development of science also shows the tendency to limit the scientific area only to things that are empirical-materialistic. Of course the tendency of such scientists was inspired by the findings of Isaac Newton (1725 AD), known as the laws of mechanics (mechanistic determinism). The discovery of this mechanical law has further alienated 
scientists from God and matters of spirituality. With Newton's mechanical law, the secret of nature's work has been exposed to scientists so that God's intervention is seen as insignificant. More than that, such a Cartesian-Newtonian mindset has also led people to think mechanically by relying on the inductive method, and measuring everything based on mathematical numbers. The term Cartesian-Newtonian Paradigm refers to the generic meaning given by Thomas Khun. Thomas Khun used this paradigm for many meanings, such as disciplinary matrices, models or thinking patterns, and the world view of scientists. This modern logic has pushed humans to limit the realm of truth to things that are empirical and material only. For example, the definition of progress in accordance with the CartesianNewtonian paradigm is the increase in human ownership and control of nature so that a nation that is able to exploit nature through industrial progress is agreed to be a nation or the first world, even though the nation is carrying out dehumanization practices.

\section{Review of Literature}

\subsection{Biography}

After completing his education in his village Nasr moved to Qum to study kalam, Sufism and especially philosophy. This is in accordance with the Iranian educational tradition which has always prioritized deep philosophical studies. Furthermore, Nasr entered MIT (Massachusetts Institute of Technology) by pursuing the field of physics. At the same time Nasr also actively participated in discussions with a group in which a number of young people with such thoughts and well-known scientists in their respective fields. At that time Nasr had attended a study on the teachings of Hindu spiritualism, which later encouraged him to like comparative religious studies.

During the study, Nasr had made a box with a number of leading intellectuals and spiritualists, which then had an urgent influence on the development of his thoughts and life. One of these figures was Rene Guenon, whose writings Nasr admired greatly. After earning a baccalaureate degree at MIT in 1954, Nasr continued his education to Harvard with a concentration in geology and geophysics; but because of his deep concern for traditional scientific disciplines. Which according to him was purer and more challenging, causing him to change the concentration of his studies into the history of science and philosophy.

In several years at Harvard, Nasr measured an amazing achievement, where he was known as a smart and well-established student at that time, even having the same authority as H.A.R. Gibb in the history and thought of Islam, Georgr Sarton in the history of science and Harry Wolfson in the history of theology and philosophy.

During his intellectual odyssey at Harvard, Nasr underwent an extraordinary change of mindset, his interaction with the phenomenon of modernization in the West which intersected with the Western tradition of values that he brought from his country forcing Nasr to change the focus of his studies.

The contact of information and thoughts that is still ongoing with scholars in his country such as Murthada Muthahari ,, Imam Khomeini and Thabthaba'I, has given him a motivation to continue enriching the trinkets of Western civilization. This then became the most important factor that made Nasr carry out the Cross Study. Besides the strong influence of the traditional religious education he received from his father. Furthermore, the informal education he obtained in the midst of the social conditions of his country as a child, is also the result of his intellectual dialogue with traditional scholars in his country.

After completing his Ph.D in the field of history of science in 1985, accompanied by the title Science and Civilization in Islam, Nasr returned to Iran and was immediately 
appointed as Professor at Tehran University and the first President of the Iranian Academy of Philosophy. 1958 was the reign of Reza Pahlavi (1941-1978) who succeeded his father. When Nasr returned, his country Reza Pahlavi was a king who had enormous ambitions to make Iran a leading industrial country in the 90s. Efforts to achieve this were carried out by accelerating the modernization process of the industrial sector and the defense and security sector, the Shah's effort was fully supported by the US, by providing assistance in the form of models, technology and even technicians. As a result, in not too long, US citizens have spread to almost all regions in Iran.This fact is driving the acceleration of the spread of Western culture in Iranian society. Iranian society as a staunch adherent of Islam, of course, could not accept the Shah's virtues, therefore there were several scholars, as well as organizations that tried to fight against this goodness. Traditional ulam appears as antiWestern and calls on the public to fight against any influence brought by the West. Then Nasr in the midst of the chaos, of course, gave birth to a controversy. Especially at the time of the Iranian revolution in 1979 which ended with the removal of Reza Pahlavi, Basr still served as Director of the Imperial Iranian, Academi of Philosophy, a prestigious position that led him to receive a knighthood from the ruling king, and was frankly supported by him.

This fact caused Nasr to have to deal with an atmosphere that was not conducive to developing his intellectual talents. He was also confronted by a number of scholars who were not appreciative, even suspicious of any new ideas he brought, especially those related to intellectual development and renewal. Furthermore, some scholars (legalists or groups of Syari'ah) actually demonstrated strong opposition to any new ideas he put forward. The peak of this opposition, can be seen when a number of scholars explicitly forbade philosophies that came from the West such as the thoughts of Karl Mark (1818-1883), Jean-Paul Sartre (19051980), and Martin Heiddeger (1989-1976) which were widely introduced Nasr.

\section{Discussion}

\section{Syed Hussein Nasr Science Concepts}

Syed Hussein Nasr is among Islamic science thinkers who sharply criticized the paradigm of modern Western science through several scientific works and lectures, such as the book the Encounter of Man and Nature (1968), the book Man and Nature: The Spiritual Crisis of Modern Man (1968), the book Islam and the Plight of Modern Man (1975), and the book Religion and the Order of Nature (1996). As did Ziauddin Sardar, Syed Naquib alAttas, and Mehdi Gholsani, Christian criticism generally leads to a secular, materialistic and mechanical world view.

Christian criticized Western science by referring to its negative impact, especially as a trigger for the crisis of spirituality, humanity and environmental crises as well as what he called the "confinement", "narrowness" and "limitations" of Western science. Criticism of the secularistic paradigm of Western science actually appears also among Western thinkers. One of the figures who is very fluent in arguing this criticism is Frithjof Capra especially in the book, The Turning Point: Science, Societey and the Rising Culture.

Some Westerners are aware that there are diseases in modern civilization. They see that their civilization has scorched human fithrah, blocked the peace of the soul, and undermined human values. Man, of course, cannot just lift himself up spiritually. He must be awakened from his nightmare by someone who has awakened. Therefore, humans need God's guidance and must follow these instructions, so that they can use all their potential and so that they can overcome obstacles in using their intellect.

Christian views on knowledge can be seen from his concept of Islamic traditionalism, but not the Islamic traditionalism that was known previously. Because, for Christians, so far 
Islamic fundamentalist or revivalist movements are no more than a dichotomy of traditionalism-modernism, their existence has become too radical and too directed towards a political mission rather than religious values. Notwithstanding such movements, in the name of traditional Islamic reforms. The society's lack of understanding of Islamic traditionalism or Islamic fundamentalism causes these two things to be considered the same. Even though the difference between the two is not only from the content but also from the activities carried out. The Islamic traditionalism movement offered by Christian is a movement to bring back the "roots of tradition"; which is "the Truth and the Source of the origin of all things", by trying to connect the secularity of the West with the divine dimension that comes from religious revelation.

This Christian offer is intended so that the sacred value of Islam can animate the knowledge that comes from in the West is more developed than the contemporary Islamic world, so that it does not need to be completely removed. Islamic traditionalism, emphasized by Nashr, is actually an initial description of a conception of thought in a Sophia Perenneis form (immortality). Islamic traditionalism can be said to be also referred to as an intellectual movement universally to be able to respond to the flow of modern Western thought which is the effect of modern philosophy which tends to be profane, and furthermore to be able to differentiate between the Islamic traditionalism movement and the Islamic fundamentalism movement, as is done in Iran., Turkey and other fundamentalist groups.

Christian efforts to roll out such an idea are at least an alternative offer of life values for modern humans and a country that has been infected with a modern mindset, with a profanic and secularistic nature, to then return to a transcendental root of tradition by making Islamic teachings. as a basic foundation for the development of science.

According to John Hendrik Meuleman, a Dutch Islamologist, Christian is an Islamic thinker who has a positive attitude towards Islamic thought in its traditional form, including certain aspects of 'irfan, which some other Islamic thinkers, for example Abid alJabiri, are not very appreciative of. This attitude was read by Meuleman because Nasr had to interact very intensively with Western thought since he settled in America after the Iranian Revolution. One of the main goals of the whole Christian thought is to emphasize and explain the superiority of Islamic tradition over modern Western thought which is considered to have left and separated from the sacred or divine and cannot understand the divine sacredness. The impact that Christian has considered bad from modern Western thought is the birth of attitudes and understandings such as individualism, rationalism, secularism and materialism.

Nasr really regrets that many Muslims today actually adopt and follow these Western attitudes and mindsets. For him, true human freedom is awareness of the basic relationship between himself and Allah SWT, as has often been explained in Islamic philosophy and Sufism. Nasr believed that true science was knowledge that knew the relationship between the worldly and the heavenly. In this frame of mind, according to Meuleman, as a Shia Muslim, Christian pays special attention to Shia thinking and the expression of spiritual values in various branches of art, which he has described in a number of books he wrote, such as the book Ideals and Relities of Islam (1966 \& 1975). , Man and Nature: The Spiritual Crisis of Modern Man (1968), Islam and the Plight of Modern Man (1975), and Islamic Art and Spirituality (1987).

Nasr's central concept of knowledge, as elaborated in the book Science and Civilization in Islam, is unity; that is, the understanding of the unity and interrelation of everything that exists, so that by contemplating the unity of the cosmos, one can lead to the divine unity envisioned in the unity of Nature. The idea of unity in science is an idea derived from the syahadah: la ilaha illa Allah. The idea of unity is not only a characteristic of Islamic science and art, it also dominates the disclosure of these sciences and arts. With the concept of unity 
or what is commonly called tauhid it also allows for the integration of diverse knowledge into an integrated one. In other words, the idea of unity enables the integration of human knowledge and action into a harmonious whole. In fact, according to Nasr, this idea of a unity was not unique to Islam but prevalent in all traditional civilizations, including Christianity.

However, its application in Islam is able to give birth to something unique, which is not found in the same degree in civilizations from other traditions. According to Nasr, cosmology is able to become a "tool of conceptual integration" because its aim is "to create a knowledge that shows the interconnectedness of all things and makes contact with the levels of the cosmic hierarchy with each other and, ultimately, with the highest principle. Thus, it becomes a knowledge that allows the integration of diversity into cohesiveness. According to him, there are differences in views and the birth of various thoughts about science, none other than because of the different levels of faculties possessed by humans, which include: intellect, imagination, ratio, and senses.

Nasr, according to Meuleman, is a follower of perennial philosophy, which is the understanding that there is a fundamental divine knowledge which in principle is achieved by everyone and is interfaith and across history. Perennial philosophy does not deny the importance of the rite and the social and social aspects of every religion but teaches that behind it lies an original tradition. According to Meuleman, perennial philosophy initially developed in the environment of Hellenistic gnosis and in Christian circles, and was later developed by Frithjof Schuon or Muhammad Isa Nuruddin, the name after converts, especially in the book Islam and the Perennial Philosophy in 1976, in addition to a number of other figures such as Rene Guenon. The influence of perennial philosophy was very visible on Nasr when he wrote the book Knowledge and the Sacred in 1981.

Perennial philosophy offered by Christian as an alternative perspective for the study of religion and religions. This is because many of the Western orientalists who have already established approaches in the study of religion are trapped into historicism. This condition risks that religion or religion loses its transcendental meaning, is uprooted from its traditional roots in the form of universal divine origin, so that it will distance religion from its center and give birth to the sorrow of modern humans. Of course, this was very disturbing for a number of "enlightened" thinkers and scholars, including Christian and his intellectual teacher, F. Schuon, a perennial figure of German descent and born in the city of Bassel, Switzerland, June 8, 1907. In an article entitled "Perennial Philosophy: Perspective Alternatives to Religious Studies ", Nasr explained the term" perennial philosophy "he meant. The term "perennial philosophy" in some writings is also used the term "perennial policy" (shopia perennis), although the two terms are not completely identical. According to Nasr, the first, "perennial philosophy", is more intellectual in nature, and the second, "perennial policy", is more of a realization.

In his tracking of the term "perennial philosophy", Nasr then elaborated that perennial philosophy has branches and branches related to cosmology, anthropology, art, and other disciplines, but at its heart lies pure metaphysics. If the word "metaphysics" is defined as knowledge of the Supreme Reality, as "knowledge of the holy" (scientia sacra), then that word or concept should not be confused with the same word in post-medieval Western philosophy. Nashr emphasized that metaphysics understood in the perspective of perennial philosophy is a true "divine knowledge", not a mental construct that will change with changing cultural styles of an era, or with the emergence of new discoveries from knowledge of the material world.

According to Nasr, when he explained the historical development of Islamic science, Muslim scientists used multiple methods in creating elements of Islamic science in accordance with the meaning of the term "science" today. Islamic science always seeks to 
apply various methods according to the nature of the subject being studied and the ways of understanding the subject. Muslim scientists, in cultivating and developing a wide variety of knowledge, have used a variety of methodologies, from rationalization and interpretation of scriptures to observation and experimentation. According to Wawan Kurniawan, Christian's presentation of Islamic science as a science that has its own methodology can be seen in various works that discuss Islamic science, for example, Science and Civilization in Islam; An Introduction to Islamic Cosmological Doctrine (Cambridge MA: Harvard University Press, 1964) and (London: Thames \& Hudson, 1978); "Islamic Science, Reflection on Methodology in the Islamic Sciences" in Hamdard Islamicus (1980: 3-13).

\section{Conclusion}

The methodology of science in Islam is based on an epistemology that is fundamentally different from the epistemology that is dominant in modern Western science. For him, faith in the revelation of the Qur'an will reveal all the possibilities that exist in human reason. Submission to revelation, at every level makes sense capable of actualizing these possibilities. The development of Muslim reason is based on a complete awareness of this principle. In this perspective, in solving philosophical and scientific problems. Hence, it is understandable why purification of the soul is seen as an integral part of the methodology of knowledge. The purification of the soul is the main concern, for the protection and proper use of human reason. The religious and spiritual atmosphere created from the Koran at the same time removes obstacles to the development of a normal and optimal mind in the right way. Intellect here, is used in the sense of origin, intellectus (Latin) or nous (Greek). In the language of the Koran it is called 'aql which means binding humans to their origin. Etymologically, intellect or 'aql has the same meaning as religion because religion binds people to God. That understanding, in modern understanding, according to Nashr in the book Knowledge and The Sacred, has been reduced to mere reasoning.

\section{References}

A. Susanto. (2011). Filsafat Ilmu (Suatu Kajian Dalam Dimensi Ontologis, Epistemologis, Aksiologis), Bumi Aksara, Jakarta.

Ach Maimun Syamsuddin. (2012). Integrasi Multidimensi Agama dan Sains, Yogyakarta: IRCiSoD.

Al-Isfahani. (1992). Mufradat Alfaz Al-Qur'an, Ed. Safwan A. Dawudi, Dar Al-Qalam, Damaskus.

Arqom Kuswanjono, Integrasi Ilmu dan Agama Perspektif Filsafat Mulla Sadra, Yogyakarta: Badan Penerbit Filsafat UGM.

Azyumardi Azra, et al. (2003) (ed.), "Nasr, Sayid Husein", dalam Suplemen Ensiklopedi Islam, (Jakarta: PT. Ichtiar Baru Van Hoeve.

Budi Handrianto. (2014). Kritik Terhadap Sains Barat Modern Persepektif Sayyed Hossein Nasr, Disampaikan dalam diskuisi Dwipekan INSIST, 8 Februari.

Cuk Ananta Wijaya. (2006). Ilmu dan Agama danlam Perspektif Filsafat Ilmu, Jurnal Filsafat Vol. 40, Nomor 2, Agustus.

Emanuel Wora. (2006). Perenialisme: Kritik Atas Modernisme dan Postmodernisme, (Yogyakarta: Kanisius)

Eugen Weber. (1956). The Western Tradition: From the Renalisance to the Present (USA: D.C. Helatand Company). 
Fank N. Magill (ed). (1990). Masterpieces of World Pholisophy: Nearly 100 Classics of Worlds Greatest Philosophers Analyed and Acsplained (USA: Library of Congress Cataloging in Publication Data).

Fitri Siska Supiatna dan Salaman Husain. (2020). Kontribusi Filsafat Perenial Sayyed Hossein Nasr Terdahap Sains Modern, (Prosiding Konferensi Integrasi Interkoneksi Islam dan Sains, Vol. 2, Maret).

Hendry, D. Aiken. (1957).The Age of Ideology: The Father of Positivisme August Comte, (the New americak Library).

Humaidi. (2015). Paradigma Sains Integratif al-Farabi: Pemikiran Filosofis Bagi Reaksi Sains, Filsafat, dan Agama, (Jakarta: Sadra Press).

Ian G. Barbour. (2005). Menemukan Tuhan Dalam Sains Kontemporer dan Agama, Mizan, Bandung.

John Hendrik Meuleman. (2002). Pergolakan Pemikiran Keagamaan, Dalam Taufik Abdullah et al, Ensiklopedia Dunia Islam Dinamika Masa Kini, Jakarta: PT. Itiar Baru Vam Hoeve.

Jujun S. Suriasumantri. (1984). Filsafat Ilmu Sebuah Pengantar Populer, Sinar Harapan, Jakata,

Komoruddin Hidayat dan Muhammad Wahyuni Nafis. (1995). Agama Masa Depan, (Jakarta: Gramedia Pustaka Utama).

Marshall G.S. Hodgson, The Venture of Islam, terj. Mulyadhi Kartanegara (Jakarta: Paramadina, 1999).

Muhammad Husayn Bahesty. (2002). Selangkah Menuju Allah: Penjelasan al-Qur'an tentang Tuhan, terj. Apep Wahyudi (Jakarta: Pustaka Zahra).

Paul Davies. (2002). Membaca Pikiran Tuhan: Dasar-dasar Ilmiah dalam Dunia Rasional, terj. Hanzah (Yogyakarta: Pustaka Pelajar)

Samuel Enoch Stumpt. (1982) Philosophy: History and Problems (USA: Mc Graw-Hull,Inc).

Seyyed Hossein Nasr. (1986). Tiga Pemikiran Islam: Ibnu Sina, Suhrawardi, dan Ibnu Arabi, terj. Ahmad Mujahid (Bandung: Risalah).

Sayyed Hossein Nasr. (1997).Pengetahuan dan Kesucian, Terj. Suharsono, (Yogyakarta: Pustaka Pelajar Offset).

Sayyed Hossein Nasr. (1986). Sain dan Peradaban Dalam Islam, (Bandung: Pustaka).

Sayyed Hossein Nasr. (1976). Three Muslim Sages, (New York: Caravan Books).

Seyyed Hossein Nasr. (1983).Islam dan Nestapa Manusia Modern, terj. A. Mahyuddin (Bandung: Pustaka).

Sayyed Hossein Nasr. (2010). In Search of The Sacred, A Conversation with Sayyed Hossen Nasr on His Life and Tahught, (England: Praeger).

Seyyed Hossen Nasr. (1993). "Pengantar", dalam Frithjof Schoun, Islam dan filsafat perenial, terj. (Bandung: Mizan).

Syarif Hidayatullah. (2018). Konsep Ilmu Pengetahuan Syed Hussein Nashr: Suatu Telaah Relasi Sains dan Agama, dalam Jurnal Filsafat, Vol. 28, No. 1.

Seyyed Hossein Nasr, Science and Civilization in Islam, (New York: The New American Library, 1970).

Seyyed Hossein Nasr. (1981). Knowledge and The Sacred, (Edinburg: Edinburg University Press).

Saefuddin, P.D. (2010). Islamisasi Sains dan Kampus, PPA Consultant, Jakarta.

Syed Muhammad Naquib Al-Attas. (1989). Islam dan Filsafat Science, Terj. Syaiful Muzani, Mizan, Bandung.

Syamsuddin, Ach. Maimun. (2012). Integrasi Multidimensi Agama \& Sains, Yogyakarta: IRCiSoD . 
Syarif Hidyatullah. (2006). Relasi Filsafat dan Agama (Perspektif Islam), Jurnal Filsafat Vol. 40, Nomor 2, Agustus.

William Chittick. (2007) "Introduction”, dalam Seyyed Hossein Nasr, The Essential Seyyed Hossein Nars, (Bloomington: World Wisdom.

Wawan Kurniawan. (2020). Pemikran Sayyed Hussein Nasr Tentang Epistemologi. https://aweygaul.wordpress.com/2012/08/09/pemikiran-seyyedhossein-nasr-tentangepistemologi/, diakses 25 Mei.

Zainal Abidin Bagir, Agama dan sains-Agama: Perbandingan Beberapa Tipologi Mutakhir ", dalam Zainal Abidin Bagir, Lik Wilardjo, Arqom Kuswanjono, dan Muhammad Yusuf (eds.), Ilmu, Etika, Dan Agama, Menyingkap Tabir Alam dan Manusia, Yogyakarta: CRCS UGM. 